\title{
ОЦІНКА ВПЛИВУ КОМПЛЕКСУ ФАКТОРІВ НА МОЛОЧНУ ПРОДУКТИВНІСТЬ КОРІВ
}

\author{
Піддубна Людмила Михайлівна \\ доктор сільськогосподарських наук, доцент \\ Поліський національний університет \\ ORCID: 0000-0002-5893-8726 \\ e-mail: I.m.poddubnaya@gmail.com \\ Захарчук Дар'я Валеріївна \\ аспірантка \\ Поліський національний університет \\ ORCID: 0000-0003-3026-4253 \\ e-mail: dashazt781@gmail.com \\ Корнійчук Дмитро Олександрович \\ магістрант \\ Поліський національний університет \\ ORCID: 0000-0003-3572-4757 \\ e-mail: dimaarabskij@gmail.com
}

Вивчено вплив генотипових та паратипових фракторів на ознаки молочної продуктивності корів-первісток українських чорно-рябої і червоно-рябої молочних та голштинської порід за вбирного схрещування в аналогічних умовах годівлі та утримання ПАФ «Єрчики» Попільнянського району Житомирської області. Встановлено переважаючий вплив генотипових фракторів на показники молочної продуктивності корів. Сила впливу породи на надій становить 2,0%, вміст жиру в молоці - 4,5%, білка - 3,9%. Надій первісток української чорно-рябої молочної породи 6470 ке, української червонорябої молочної - 6630 ке, голштинської - 6666 ке за найвищих показників вмісту жиру і білка в молоці - 3,83 і 3,11 \% відповідно. Сила впливу лінійної належності на надій становить 3,6 \%, вміст жиру в молоці - 14,7 \%, білка - 15,4 \%. Найвищі показники молочної продуктивності мають первістки ліній Валіанта 1650414, Джоско Бесна 5694028588, Чіра 1427381 надій 6701-6878 ка, вміст жиру в молоці 3,82-3,86 \%, білка - 3,08-3,14 \%. Різниця тах-тіп між тваринами різних ліній за названими показниками становить відповідно 811 ке, 0,15 і 0,13%. Зумовленість ознак молочної продуктивності дочок генотипом батька найбільша - надою 11,4 \%, вмісту жиру і білка в молоці - 31,0 і 31,5 \% відповідно. Залежно від походженням за батьком різниця тах-тіп становить за надоєм 1820 ке, вмістом жиру - 0,21 \%, білка - 0,17 \%. Особливо цінними у селекційному плані є два бугаї - Коугар 65439939 і Джарвіс 66683713, їхні дочки поєднують високі надої (понад 7 тис. к己 за 305 днів лактації) з максимальними вмістом жиру і білка в молоці (3,90 і 3,17 \% відповідно). Серед паратипових фракторів найбільший вплив на молочну продуктивність має рік отелення, зумовленість ним надою становить 14,1\%, вмісту жиру і білка в молоці - 30,4-30,6 \%. Упродовж 4-5 років зростання надою склало 1281 ке, вмісту жиру в молоці 0,17 \%, білка - 0,14 \%. Вплив віку і сезону отелення на надій первісток незначний - 0,7-2,7 \%. Доведено суттєвий вплив живої маси первісток при першому отеленні на їх надій (20,9\%), що свідчить про необхідність інтенсивного вирощування молодняку.

Ключові слова: фрактор впливу, молочна продуктивність, порода, лінія, бугай-плідник, вік отелення, рік та сезон отелення, жива маса.

DOI: https://doi.org/10.32845/bsnau.Ivst.2021.2.17

Світовою та вітчизняною практикою доведено, що рентабельність молочного скотарства залежить від продуктивності великої рогатої худоби молочних порід. Інтенсиффікація виробництва в молочному скотарстві зумовила нов вимоги до молочних корів, проте найважливішою лишається їх високий рівень продуктивності, а ще придатність до машинного доїння, здатність зберігати високі надої за дворазового доїння, високі технологічність вим'я та відтворювальна здатність, стійкість до захворювань та тривале господарське використання [23].

Молочна продуктивність - полігенна ознака, зумовлена складним генетичним комплексом і факторами зовнішнього середовища, має високу амплітуду мінливості. Тому більшість науковців справедливо вважають, що у селекційно-племінній роботі з популяціями молочної худоби необхідно враховувати як генотипові, так і паратипові чинники

впливу в конкретних господарсько-кліматичних умовах $[3,6,7,16,29]$.

Генетичний потенціал молочної продуктивності корів залежить насамперед від породи, кожна порода характеризується властивими їй біологічними, селекційногенетичними та господарськи корисними ознаками, що формуються в певних умовах середовища і зумовлені спадковістю тварин [2,30]. Наразі у вітчизняних племінних стадах $\epsilon$ найпродуктивнішими і використовуються найбільш інтенсивно тварини голштинської, українських чорно-рябої та червоно-рябої молочних порід $[5,19]$.

Численні дослідження вказують на суттєву роль ліній у поліпшенні порід і стад молочної худоби, а саме в передачі цінних властивостей родоначальника групі тварин і здатності у кожному наступному поколінні відтворювати плідників, які за властивостями не поступаються родоначальнику або 
навіть переважають його $[1,11,24,25]$. Доведено також, що удосконалення племінних стад великої рогатої худоби залежить від походження за батьком, тобто генотипу бугая, тому оцінка бугаїв-плідників за продуктивністю дочок та виявлення поліпшувачів, які стійко передають свої цінні ознаки потомству, є одним із найважливіших прийомів удосконалення продуктивних, технологічних і племінних якостей молочної та комбінованої худоби $[15,17,21,25]$.

Поряд з цим, фенотиповий прояв продуктивних ознак $€$ наслідком взаємодії спадкової основи організму (генотипу) з умовами навколишнього середовища, в яких він росте і розвивається. Тому можливість реалізації генетичного потенціалу молочної продуктивності тварин кожної породи і лінії визначають такі елементи технології як рівень вирощування молодняку, критерієм якого є жива маса на певному етапі розвитку, спосіб утримання та рівень годівлі корів, показники відтворення й ветеринарного забезпечення тощо $[13,26,27,28]$. Окрім технологічних фракторів, на формування молочної продуктивності корів впливають природнокліматичні умови. До основних середовищних факторів впливу на молочну продуктивність відносяться рік та сезон народження і першого отелення корів [7, 9,18,20].

Отже, врахування та поєднання максимальної кількості генетичних та паратипових фракторів $€$ вагомим механізмом підвищення продуктивності великої рогатої худоби молочних порід. Особливо актуальним він є у стадах вітчизняних молочних порід за тотального використання чистопородних голштинських бугаїв зарубіжної селекції, тому що підвищення їх продуктивності за рахунок відтворного чи вбирного схрещування уже себе вичерпало. Враховуючи зазначене вище, метою наших досліджень $€$ вивчення впливу комплексу факторів на ознаки молочної продуктивності корів-первісток українських чорно-рябої і червоно-рябої молочних та голштинської порід в умовах ПАФ «Ерчики» Попільнянського району Житомирської області.

Матеріали та методи досліджень. Дослідження проведено шляхом аналізу матеріалів племінного та продуктивного використання корів-первісток племзаводів приватної агрофірми (ПАФ) «Єрчики» Житомирської області у традиційних умовах прив'язного утримання. Для дослідження відібрано 181 корову української чорно-рябої породи, 42 української червоно-рябої та 257 - голштинської, отриманих у господарстві шляхом вбирного схрещування маточного поголів'я вітчизняних порід з чистопородними голштинськими бугаями-плідниками. Галузь молочного скотарства ПАФ «Єрчики» забезпечена відповідними умовами догляду, утримання та годівлі тварин.

Молочну продуктивність за першу лактацію досліджували за надоєм за 305 днів або скорочену лактацію (не менше 240 днів) шляхом проведення контрольних доїнь тричі на місяць упродовж перших трьох місяців і щомісячно до закінчення лактації з одночасним визначенням у добових зразках молока відсотку жиру і білка на приладі «Екомілк КАМ-98.2А». Ступінь впливу різних фракторів на молочну продуктивність корів-первісток визначали відношенням факторіальної дисперсії до загальної в однофакторному дисперсійному комплексі. Обробку первинних даних проводили методами варіаційної статистики, використовуючи комп'ютерну програму "MS Office Excel 2010".

Результати досліджень. Тварини стада ПАФ «Єрчики» мають високий потенціал молочної продуктивності, середній надій корів за останніх 3 роки становив 7-8 тис. кг молока за лактацію. Частка голштинської спадковості корів вітчизняних порід досить висока і складає по українській червоно-рябій молочній породі 85,5\%, українській чорнорябій - 91,4%. Для більшої об'єктивності досліджень використані корови-первістки, відбір серед яких мінімальний. По обстеженому поголів'ю надій за 305 днів лактації складає 6589 кг, вміст жиру в молоці - 3,81\%, білка - 3,09 \%, вік першого отелення - 28 міс., жива маса корів при першому отеленні - 529,1 кг.

Надій корів-первісток залежно від породи коливається від 6470 кг (українська чорно-ряба молочна) до 6666 кг (голштинська) за невірогідної різниці, що пояснюється переважним впливом на вітчизняні породи голштинів та аналогічними умовами утримання і використання. За якісними показниками молочної продуктивності перевага належить первісткам голштинської породи, вмістом жиру - 0,03-0,05 $\%$, білка - 0,04 \% (P<0,001). Це зумовило вірогідну перевагу голштинських первісток над ровесницями української чорнорябої молочної породи за продукцією молочного жиру і білка - 10,5 і 8,5 кг відповідно (Р<0,05) (табл. 1).

Молочна продуктивність первісток залежно від породи

\begin{tabular}{|l|c|c|c|c|c|c|}
\hline \multicolumn{1}{|c|}{ Порода } & $\mathrm{n}$ & Надій, кг & Вміст жиру, \% & Молочний жир, кг & Вміст білка, \% & Молочний білок, кг \\
\hline Українська чорно-ряба молочна & 181 & $6470 \pm 87,8$ & $3,78 \pm 0,009$ & $245,0 \pm 3,50$ & $3,07 \pm 0,007$ & $198,7 \pm 2,80$ \\
\hline Українська червоно-ряба молочна & 42 & $6630 \pm 136,7$ & $3,80 \pm 0,015$ & $252,2 \pm 5,83$ & $3,07 \pm 0,016$ & $203,7 \pm 4,67$ \\
\hline Голштинська & 257 & $6666 \pm 72,5$ & $3,83 \pm 0,006$ & $255,5 \pm 2,90$ & $3,11 \pm 0,006$ & $207,2 \pm 2,37$ \\
\hline Різниця maх-min & & $196 \pm 113,9$ & $0,05 \pm 0,011^{* * *}$ & $10,5 \pm 4,55^{*}$ & $0,04 \pm 0,009^{* * *}$ & $8,5 \pm 3,67^{*}$ \\
\hline
\end{tabular}

Наразі генеалогічна структура поголів'я племінних заводів не контролюється централізовано регіональними селекційними центрами, власники та керівники господарств обирають постачальників спермопродукції самостійно. Це ускладнює виявлення особливостей господарськи корисних ознак тварин певної лінії та її специфіки.

Нашими дослідженнями встановлено, що корови досліджуваних ліній відрізняються за ознаками молочної продуктивності, що свідчить про спадковий вплив генеалогічних формувань на їхню варіабельність. Найвищі показники молочної продуктивності мають первістки трьох ліній - Валіанта, Джоско Бесна, Чіфа, а саме: надій 6701-6878 кг, вміст жиру в молоці 3,82-3,86 \%, продукція молочного жиру 259,0264,2 кг, вміст білка в молоці 3,08-3,14 \%, продукція молочного білка - 208,8-214,3 кг. Різниця між тваринами найбільш продуктивної лінії (Чіфа) і найменш продуктивної (Маршала) за названими показниками становить відповідно 811 кг; 0,15 \%; 33,6 кг; 0,13 \%; 27,6 кг (Р<0,001) (табл. 2). 
Таблиия 2

Молочна продуктивність первісток залежно від належності до лінії

\begin{tabular}{|l|c|c|c|c|c|c|}
\hline \multicolumn{1}{|c|}{ Лінія } & $\mathrm{n}$ & Надій, кг & Вміст жиру, \% & Молочний жир, кг & Вміст білка, \% & Молочний білок, кг \\
\hline Валіанта 1650414 & 58 & $6784 \pm 136,6$ & $3,82 \pm 0,012$ & $259,0 \pm 5,18$ & $3,08 \pm 0,008$ & $208,8 \pm 4,28$ \\
\hline Джоско Бесна 5694028588 & 105 & $6701 \pm 126,1$ & $3,86 \pm 0,009$ & $259,2 \pm 5,14$ & $3,14 \pm 0,007$ & $211,1 \pm 4,18$ \\
\hline Елевейшна 1491007 & 17 & $6309 \pm 195,6$ & $3,73 \pm 0,024$ & $235,8 \pm 7,97$ & $3,01 \pm 0,021$ & $190,5 \pm 6,49$ \\
\hline Кавалера 1620273 & 14 & $6321 \pm 124,4$ & $3,71 \pm 0,022$ & $234,1 \pm 4,39$ & $3,02 \pm 0,025$ & $190,5 \pm 3,41$ \\
\hline Маршала 2290977 & 35 & $6067 \pm 178,3$ & $3,80 \pm 0,021$ & $230,6 \pm 7,23$ & $3,07 \pm 0,017$ & $186,7 \pm 6,03$ \\
\hline Старбака 352790 & 182 & $6499 \pm 83,3$ & $3,78 \pm 0,008$ & $245,9 \pm 3,34$ & $3,06 \pm 0,007$ & $199,3 \pm 2,65$ \\
\hline Чіфа 1427381 & 69 & $6878 \pm 143,2$ & $3,84 \pm 0,010$ & $264,2 \pm 5,54$ & $3,12 \pm 0,009$ & $214,3 \pm 4,52$ \\
\hline Різниця maх-min & $811 \pm 228,7^{* * *}$ & $0,15 \pm 0,024^{* * *}$ & $33,6 \pm 9,11^{* * *}$ & $0,13 \pm 0,022^{* * *}$ & $27,6 \pm 7,54^{* * *}$ \\
\hline
\end{tabular}

Піддослідне поголів'я відноситься до потомства 20 бугаїв-плідників. Для вивчення ознак молочної продуктивні залежно від походження за батьком нами відібрано 15 плідників, які мали 10 і більше дочок. Найвищими надоями (6887-7264 кг, що на 300 кг і більше переважає середню по стаду) характеризуються дочки бугаїв Сарукко, Боуліварда, Джарвіса, Коугара. Найбільш суттєва різниця за кількісними показниками виявлена між дочками бугаїв Альтаматтео і Коугара на користь останнього, за надоєм 1820 кг, продукцією молочного жиру - 83,2 кг, білка - 67,2 кг. Найвищі якісні показники молочної продуктивності (відсоток жиру 3,84-3,90,

білка $3,14-3,17)$ притаманні дочкам бугаїв Гон Голда, Джарвіса, Коугара, Седдіна, Фаста. Зоотехнічною практикою доведено, що між величиною надою та вмістом жиру і білка в молоці у переважній більшості випадків існує від'ємний кореляційний зв'язок, або незначний додатній, що ускладнює одночасну селекцію за цими двома ознаками. Тому слід відмітити, що особливо цінними у селекційному плані $€$ два бугаї - Коугар (лінія Старбака) і Джарвіс (Чіфа), їхні дочки поєднують високі надої (понад 7 тис. кг за 305 днів лактації) з максимальними вмістом жиру і білка в молоці (3,90 і 3,17 \% відповідно) (табл. 3).

Таблиця 3

Молочна продуктивність первісток залежно від походження за батьком

\begin{tabular}{|l|c|c|c|c|c|c|}
\hline \multicolumn{1}{|c|}{ Кличка бугая } & $\mathrm{n}$ & Надій, кг & Вміст жиру, \% & Молочний жир, кг & Вміст білка, \% & Молочний білок, кг \\
\hline Альтаматтео 63467820 & 13 & $5444 \pm 290,2$ & $3,69 \pm 0,028$ & $200,7 \pm 10,89$ & $3,00 \pm 0,020$ & $163,5 \pm 9,04$ \\
\hline Арудольф 135905690 & 10 & $6070 \pm 260,2$ & $3,80 \pm 0,015$ & $230,9 \pm 10,20$ & $3,03 \pm 0,034$ & $183,6 \pm 7,66$ \\
\hline Боулівард 62771837 & 28 & $6925 \pm 188,2$ & $3,81 \pm 0,009$ & $264,4 \pm 7,39$ & $3,09 \pm 0,009$ & $213,9 \pm 5,82$ \\
\hline Гон Голд 62336854 & 15 & $6498 \pm 376,0$ & $3,84 \pm 0,033$ & $249,6 \pm 14,19$ & $3,14 \pm 0,025$ & $203,7 \pm 11,75$ \\
\hline Джарвіс 66683713 & 20 & $7181 \pm 291,4$ & $3,90 \pm 0,015$ & $279,7 \pm 11,07$ & $3,17 \pm 0,006$ & $227,7 \pm 9,17$ \\
\hline Канцлер 768305280 & 12 & $6330 \pm 124,8$ & $3,71 \pm 0,025$ & $234,1 \pm 4,40$ & $3,02 \pm 0,028$ & $190,5 \pm 3,43$ \\
\hline Кармелло 349214112 & 30 & $5897 \pm 174,1$ & $3,72 \pm 0,021$ & $219,8 \pm 6,98$ & $3,09 \pm 0,021$ & $182,0 \pm 5,50$ \\
\hline Кларіті 534768616 & 24 & $6724 \pm 221,5$ & $3,83 \pm 0,014$ & $257,6 \pm 8,87$ & $3,10 \pm 0,019$ & $208,5 \pm 7,30$ \\
\hline Коугар 65439939 & 10 & $7264 \pm 325,2$ & $3,90 \pm 0,018$ & $283,9 \pm 13,84$ & $3,17 \pm 0,013$ & $230,7 \pm 10,91$ \\
\hline Масіро 354071654 & 14 & $6315 \pm 196,0$ & $3,73 \pm 0,025$ & $235,8 \pm 7,81$ & $3,01 \pm 0,022$ & $190,5 \pm 6,52$ \\
\hline Сарукко 350995813 & 48 & $6887 \pm 173,0$ & $3,78 \pm 0,018$ & $261,0 \pm 6,85$ & $3,07 \pm 0,011$ & $211,2 \pm 5,31$ \\
\hline Седдін 352642486 & 105 & $6701 \pm 126,1$ & $3,86 \pm 0,009$ & $259,2 \pm 5,14$ & $3,14 \pm 0,007$ & $211,1 \pm 4,18$ \\
\hline Сідней 9428124 & 53 & $6779 \pm 139,1$ & $3,82 \pm 0,013$ & $259,0 \pm 5,20$ & $3,08 \pm 0,008$ & $208,8 \pm 4,31$ \\
\hline Фаст 63683062 & 15 & $6610 \pm 203,2$ & $3,85 \pm 0,019$ & $254,8 \pm 8,05$ & $3,16 \pm 0,013$ & $208,7 \pm 6,89$ \\
\hline Ширлі 447860719 & 38 & $6408 \pm 183,0$ & $3,73 \pm 0,011$ & $239,6 \pm 6,96$ & $3,00 \pm 0,018$ & $192,2 \pm 5,63$ \\
\hline Різниця тах-min & & $1820 \pm 435,9^{* * *}$ & $0,24 \pm 0,045^{* * *}$ & $83,2 \pm 17,61^{* * *}$ & $0,17 \pm 0,019^{* * *}$ & $67,2 \pm 14,17^{* * *}$ \\
\hline
\end{tabular}

Інтенсивне вирощування та вибір оптимального часу осіменіння і отелення ремонтних телиць дає змогу комплектувати племінні стада первістками з високим потенціалом продуктивності. Дослідження Новака І. В., Федоровича В. В. та Федорович Є. I свідчить про досить суттєвий вплив віку першого отелення (16,3-26,3 \%) на надій корів [14]. Зрозуміло, що раннє отелення збільшує тривалість господарського використання корів. На думку Гавриленко М. С., раннім для корів української чорно-рябої молочної породи слід вважати отелення у віці менше 24 міс., оптимальним - 24-29, пізнім більше 30 [8].

У підконтрольному стаді у віці до 24 місяців отелилося лише 6,5 \% первісток. Це переважно первістки голштинської породи, вони мають досить високий надій - 6808 кг та максимальні вміст жиру і білка в молоці - 3,84 і 3,11 \% відповідно. Переважна більшість первісток (70 \%) розтелилась у віці від 24 до 29 місяців, їхні показники із збільшенням віку отелення мають тенденцію до зниження і загалом знаходяться в межах: надій за 305 днів лактації - 6427-6650 кг, вміст жиру в молоці - 3,79-3,83 \%, білка - 3,08-3,10 \%, продукція молочного жиру - 244,1-254,9 кг, білка - 198,2-206,3 кг. У первісток, що отелились у віці 30-33 міс., спостерігається зростання кількісних показників молочної продуктивності: надою до 6940 кг, продукції молочного жиру - до 263,7 кг, білка - до 213,5 кг. Найнижчі кількісні показники характерні для первісток, що отелились у віці 33 міс. і більше - надій 6318 кг, продукція молочного жиру 239,9 кг, білка - 195,5 кг (табл. 4). 
Молочна продуктивність первісток залежно від віку отелення

\begin{tabular}{|l|c|c|c|c|c|c|}
\hline Вік першого отелення, міс & $\mathrm{n}$ & Надій, кг & Вміст жиру, \% & Молочний жир, кг & Вміст білка, \% & Молочний білок, кг \\
\hline До 24 & 31 & $6808 \pm 991,2$ & $3,84 \pm 0,064$ & $261,6 \pm 40,03$ & $3,11 \pm 0,087$ & $211,6 \pm 32,07$ \\
\hline $24-25$ & 111 & $6650 \pm 114,1$ & $3,83 \pm 0,009$ & $254,9 \pm 4,62$ & $3,10 \pm 0,009$ & $206,3 \pm 3,76$ \\
\hline $26-27$ & 132 & $6569 \pm 101,3$ & $3,81 \pm 0,010$ & $250,7 \pm 4,09$ & $3,09 \pm 0,008$ & $203,1 \pm 3,34$ \\
\hline $28-29$ & 94 & $6427 \pm 116,7$ & $3,79 \pm 0,012$ & $244,1 \pm 4,70$ & $3,08 \pm 0,012$ & $198,2 \pm 3,77$ \\
\hline $30-31$ & 45 & $6495 \pm 171,5$ & $3,81 \pm 0,016$ & $244,9 \pm 6,76$ & $3,09 \pm 0,012$ & $200,7 \pm 5,47$ \\
\hline $32-33$ & 42 & $6940 \pm 154,0$ & $3,77 \pm 0,015$ & $263,7 \pm 6,24$ & $3,06 \pm 0,011$ & $213,5 \pm 4,86$ \\
\hline Понад 33 & 25 & $6318 \pm 234,5$ & $3,80 \pm 0,023$ & $239,9 \pm 8,97$ & $3,09 \pm 0,018$ & $195,2 \pm 7,34$ \\
\hline Різниця max-min & $622 \pm 280,5^{*}$ & $0,07 \pm 3,771$ & $23,8 \pm 10,93^{*}$ & $0,05 \pm 0,088$ & $18,3 \pm 8,80^{*}$ \\
\hline
\end{tabular}

Отже, за результатами першої лактації спостерігається залежність молочної продуктивності від віку отелення корів, проте вона не відповідає нормальному розподілу і пояснюється, ймовірніше за все, індивідуальними особливостями первісток, тобто їхнім загальним розвитком та породною належністю. Тому визначити оптимальний вік першого отелення для такого змішаного стада досить складно.

Сезон отелення впливає на рівень молочної продуктивності в силу того, що він зумовлює зміну умов годівлі та кліматичних факторів. Більшість дослідників бажаними називають осінні і зимові отелення і відмічають, що тоді лактаційна крива корів більш вирівняна і вони мають вищі надої на 2-10 \% [18,20]. Це має ще й суто біологічне підґрунтя - осінньо-зимові телята зазвичай міцніші і життєздатні, оскільки інтенсивний розвиток плоду відбувається в умовах літнього біологічно повноцінного живлення матерів, а післямолочне вирощування телят припадає на весняний період, забезпечуючи їм інтенсивний розвиток. Нашими дослідженнями підтверджено, що молочна продуктивність корів певною мірою залежить від сезону їхнього отелення. Вищі надої за 305 днів лактації спостерігаються у корів, які отелились в осінньо-зимовий період (6677-6687 кг), нижчі - веснянолітній (6440-6573 кг). Проте різниця не є вірогідною, що пояснюється, на нашу думку, рівномірним забезпеченням тварин повноцінними кормами упродовж року. Максимальні якісні показники молочної продуктивності зафіксовано взимку - відсоток жиру 3,82, білка 3,12, мінімальні восени - 3,76 і 3,06 відповідно (табл. 5).

Таблиия 5

Молочна продуктивність первісток залежно від сезону отелення

\begin{tabular}{|l|c|c|c|c|c|c|}
\hline Сезон отелення & $\mathrm{n}$ & Надій, кг & Вміст жиру, \% & Молочний жир, кг & Вміст білка, \% & Молочний білок, кг \\
\hline Зима & 120 & $6677 \pm 92,0$ & $3,82 \pm 0,008$ & $256,1 \pm 3,52$ & $3,12 \pm 0,008$ & $208,5 \pm 2,97$ \\
\hline Весна & 115 & $6573 \pm 100,5$ & $3,81 \pm 0,007$ & $250,9 \pm 3,77$ & $3,10 \pm 0,007$ & $204,0 \pm 3,12$ \\
\hline Літо & 132 & $6440 \pm 93,9$ & $3,81 \pm 0,007$ & $245,5 \pm 3,75$ & $3,07 \pm 0,005$ & $198,0 \pm 3,02$ \\
\hline Осінь & 113 & $6687 \pm 108,8$ & $3,76 \pm 0,010$ & $252,2 \pm 4,41$ & $3,06 \pm 0,007$ & $204,7 \pm 3,62$ \\
\hline Різниця тах-min & $247 \pm 143,7$ & $0,06 \pm 0,013^{\star * \star}$ & $10,6 \pm 5,14^{*}$ & $0,06 \pm 0,011^{* \star *}$ & $10,5 \pm 4,24^{*}$ \\
\hline
\end{tabular}

Літературні джерела містять також повідомлення про вплив року отелення корів на їхню молочну продуктивність $[6,12,19]$, він зумовлений кліматичними, господарськоекономічними та селекційними факторами. Проведені нами дослідження свідчать про суттєве збільшення продуктивності молочного стада упродовж 2015-2018 років: зростання надою склало 1281 кг, вмісту жиру в молоці - 0,16 \%, білка 0,12 \%, продукції молочного жиру - 51,9 кг, молочного білка
- 42,5 кг $(\mathrm{P}<0,001)$. У 2019 році за зниження надою на 804 кг спостерігається подальше зростання вмісту жиру і білка, ці показники досягають 3,86 і 3,14 відсотка відповідно. Отже, ефект поглинання голштинами українських чорно- і червоно-рябих молочних порід у процесі селекції призводить одночасно до збільшення як надою, так і вмісту жиру та білка в молоці (табл.6).

Молочна продуктивність первісток залежно від року отелення

\begin{tabular}{|l|c|c|c|c|c|c|}
\hline Рік отелення & $\mathrm{n}$ & Надій, кг & Вміст жиру, \% & Молочний жир, кг & Вміст білка, \% & Молочний білок, кг \\
\hline 2015 & 36 & $5934 \pm 115,4$ & $3,69 \pm 0,017$ & $219,2 \pm 4,68$ & $3,06 \pm 0,010$ & $181,4 \pm 3,82$ \\
\hline 2016 & 59 & $6030 \pm 147,7$ & $3,70 \pm 0,009$ & $223,0 \pm 5,51$ & $3,00 \pm 0,016$ & $180,3 \pm 4,32$ \\
\hline 2017 & 124 & $6569 \pm 89,1$ & $3,79 \pm 0,007$ & $249,2 \pm 3,34$ & $3,05 \pm 0,007$ & $200,2 \pm 2,76$ \\
\hline 2018 & 131 & $7215 \pm 97,6$ & $3,85 \pm 0,007$ & $278,3 \pm 3,92$ & $3,12 \pm 0,005$ & $225,5 \pm 3,15$ \\
\hline 2019 & 130 & $6411 \pm 100,5$ & $3,86 \pm 0,009$ & $247,5 \pm 4,05$ & $3,14 \pm 0,007$ & $201,8 \pm 3,33$ \\
\hline Різниця max-min & $1281 \pm 151,1^{* \star *}$ & $0,17 \pm 0,019^{* \star *}$ & $59,1 \pm 6,10^{* * *}$ & $0,14 \pm 0,017^{* * *}$ & $45,2 \pm 5,35^{\star * *}$ \\
\hline
\end{tabular}

Молочна продуктивність корів значною мірою зумовлена їхньою живою масою, адже вона є інтегральним показником загального розвитку та вгодованості тварин. Крім того, великі тварини можуть споживати більшу кількість кормів, необхідних для продукування молока, вони мають краще розвинені грудну клітину та кровоносну систему. Високу молочну продуктивність первісток можна отримати лише за інтенсивного вирощування ремонтних телиць $[4,10,13]$, тоді вони будуть нормально розвинені і підготов- лені до отелення. Проведені дослідження переконливо свідчать про вплив живої маси первісток на молочну продуктивність, за її збільшення з 450 до 650 кг зростання надою складає 1677 кг, продукції молочного жиру - 66,4 кг, білка 52,7 кг. Подальше збільшення живої маси не супроводжується суттєвим підвищенням показників молочної продуктивності, проте вони лишаються на досить високому рівні 6972-7179; 264,5-270,8 і 215,0-222,2 кг відповідно (табл. 7). 
Молочна продуктивність залежно від живої маси при першому отеленні

\begin{tabular}{|l|c|c|c|c|c|c|}
\hline \multicolumn{1}{|c|}{ Жива маса, кг } & $\mathrm{n}$ & Надій, кг & Вміст жиру, \% & Молочний жир, кг & Вміст білка, \% & Молочний білок, кг \\
\hline До 451 & 71 & $5554 \pm 161,3$ & $3,76 \pm 0,014$ & $209,9 \pm 6,42$ & $3,07 \pm 0,011$ & $171,0 \pm 5,24$ \\
\hline $451-500$ & 130 & $6358 \pm 80,1$ & $3,80 \pm 0,010$ & $241,6 \pm 3,24$ & $3,09 \pm 0,009$ & $196,4 \pm 2,61$ \\
\hline $501-550$ & 139 & $6898 \pm 77,7$ & $3,83 \pm 0,009$ & $264,2 \pm 3,12$ & $3,10 \pm 0,008$ & $214,0 \pm 2,54$ \\
\hline $551-600$ & 57 & $6778 \pm 129,9$ & $3,82 \pm 0,013$ & $259,0 \pm 5,13$ & $3,08 \pm 0,014$ & $209,0 \pm 4,23$ \\
\hline $601-650$ & 55 & $7231 \pm 156,8$ & $3,82 \pm 0,013$ & $276,3 \pm 6,38$ & $3,09 \pm 0,011$ & $223,7 \pm 5,22$ \\
\hline $651-700$ & 23 & $6972 \pm 195,4$ & $3,80 \pm 0,017$ & $264,5 \pm 7,78$ & $3,08 \pm 0,015$ & $215,0 \pm 6,32$ \\
\hline Понад 700 & 5 & $7179 \pm 350,8$ & $3,77 \pm 0,037$ & $270,8 \pm 15,42$ & $3,09 \pm 0,025$ & $222,2 \pm 12,47$ \\
\hline Різниця тах-min & & $1677 \pm 225,0^{\star \star *}$ & $0,07 \pm 0,017^{\star \star *}$ & $66,4 \pm 9,05^{\star \star *}$ & $0,03 \pm 0,014^{*}$ & $52,7 \pm 7,40^{\star \star *}$ \\
\hline
\end{tabular}

За результатами однофакторного дисперсійного аналізу встановлено, що показники молочної продуктивності корів-первісток на 2,0-31,5\% залежать від генотипових факторів. Найсильнішим чинником $€$ походження за батьком, його вплив на надій становить $11,4 \%$, вміст жиру і білка в молоці - 31,0-31,5 \% (P<0,001). На другому місці лінійна належність, ії̈ вплив на названі показники складає 3,6 і 14,7$15,5 \%$ відповідно, на останньому - порода із показниками $2,0$ і $3,9-4,5 \%$ ( $P<0,001 \ldots 0,05)$. Аналогічну зумовленість ознак молочної продуктивності генотиповими факторами відмічають багато дослідників $[1,3,17,22,25]$, зокрема за даними фахівців Інституту розведення і генетики тварин Гладія М.В., Коваленка Г. С., Прайми С.В. та ін., вплив бугая на надій дочок залежно від лактації і породи становить 15,4-47,9 \%, вміст жиру - 22,0-43,4 \%; лінії 6,1-24,5 і 4,1-17,1 \% відповідно; породи - 0,3-2,9 і 0,2-0,3 \%. Серед паратипо- вих чинників найбільший вплив на молочну продуктивність має рік отелення, зумовленість ним надою становить 14,1 $\%$, вмісту жиру і білка в молоці - 30,4-30,6 \%. На нашу думку, основною складовою цього впливу $є$ цілеспрямований підбір плідників за вбирного схрещування. Вплив віку і сезону отелення на надій первісток незначний і складає 0,7$2,7 \%$, натомість сезон отелення зумовлює на 5,0-6,3\% вміст жиру і білка в молоці. За літературними даними, зумовленість показників молочної продуктивності паратиповими чинниками (роком і сезоном народження та першого отелення) коливається в межах від 0,28 до 17,7 \% [6,9,12,18,20]. Нашими дослідженнями встановлено також суттєвий вплив живої маси первісток при першому отеленні на їх надій $(20,9$ \%), що свідчить про необхідність інтенсивного вирощування молодняку (табл. 8).

Сила впливу генотипових і паратипових фракторів на ознаки молочної продуктивності корів (n=480)

\begin{tabular}{|c|c|c|c|c|c|c|c|c|}
\hline \multirow{3}{*}{ Фактор впливу } & \multirow{3}{*}{$\begin{array}{c}\text { Число } \\
\text { градацій }\end{array}$} & \multirow{3}{*}{$F_{\text {kpum }}$} & \multicolumn{6}{|c|}{ Частка впливу на ознаку } \\
\hline & & & \multicolumn{2}{|c|}{ Надій, кг } & \multicolumn{2}{|c|}{ Вміст жиру, \% } & \multicolumn{2}{|c|}{ Вміст білка, \% } \\
\hline & & & $\eta_{x}^{2}$ & $F_{\text {факт }}$ & $\eta_{x}^{2}$ & $F_{\text {факт }}$ & $\eta_{x}^{2}$ & $F_{\text {факт }}$ \\
\hline Порода & 3 & 3,01 & $0,020^{*}$ & 4,40 & $0,045^{\star \star *}$ & 11,12 & $0,039^{* * *}$ & 9,62 \\
\hline Лінія & 7 & 2,12 & $0,036^{*}$ & 2,92 & $0,147^{\star \star *}$ & 13,62 & $0,154^{* * *}$ & 14,4 \\
\hline Походження за батьком & 20 & 1,61 & $0,114^{\star \star *}$ & 3,10 & $0,310^{\star \star \star}$ & 10,86 & $0,315^{\star \star *}$ & 9,72 \\
\hline Вік отелення & 7 & 2,12 & $0,027^{*}$ & 2,15 & 0,024 & 1,96 & 0,013 & 1,06 \\
\hline Сезон отелення & 4 & 2,62 & 0,007 & 1,09 & $0,050^{* * *}$ & 8,43 & $0,063^{* * *}$ & 10,66 \\
\hline Рік отелення & 5 & 2,39 & $0,141^{* \star *}$ & 19,49 & $0,306^{* \star *}$ & 56,21 & $0,304^{* * *}$ & 51,95 \\
\hline Жива маса & 7 & 2,12 & $0,209^{\star * \star}$ & 20,86 & $0,041^{*}$ & 3,37 & 0,011 & 0,86 \\
\hline
\end{tabular}

Висновки. Серед оцінених факторів за існуючих умов годівлі та утримання корів у ПАФ «Єрчики» суттєвий вплив на молочну продуктивність мають походження за батьком - надій 11,4\%, вміст жиру в молоці $31,0 \%$, білка 31,5 \%, та лінійна належність - 3,6; 14,7 і 15,4 \% відповідно. Отримані дані $є$ підірунтям для подальшої голштинізації за цілеспрямованої селекційної роботи у стаді молочної худоби даного господарства. Про її ефективність переконливо свідчить значний вплив року отелення на молочну продуктивність первісток.

Для підвищення темпів генетичного прогресу за молочною продуктивністю стада доцільно проводити добір корів ліній Валіанта 1650414, Джоско Бесна 5694028588 та Чіфра 1427381, серед бугаїв для поліпшення якісних показників молока інтенсивно використовувати Гон Голда 62336854 , Джарвіса 66683713, Коугара 65439939, Седдіна 352642486, Фаста 63683062.

Значним резервом підвищення молочної продуктивності $€$ інтенсивне вирощування молодняку, про що свідчить висока обумовленість надою живою масою первісток за отелення - 20,9\%. Виявлена незначна перевага корів осінньо-зимових отелень на весняно-літніми може цілком нівелюватись за умови рівномірного кормозабезпечення тварин упродовж року.

\section{Список використаної літератури:}

1. Базишина І. В. Формування господарськи корисних ознак молочної худоби в залежності від походження за батьком, лінії та спорідненої групи. Розведення і генетика тварин. Київ, 2017. Вип. 53. С. 69-78.

2. Буркат В. П. Десять років від дня набуття Укрплемоб'єднанням статусу національного об'єднання по племінній справі у тваринництві. К.: Аграрна наука, 2003. 39 с.

3. Ведмеденко О. В. Вплив генотипових та паратипових факторів на молочну продуктивність корів. Подільський вісник: сільське господарство, техніка, економіка. Камянець-Подільський, 2019. Вип. 30. С.31-38.

4. Ведмеденко О. В. Молочна продуктивність корів залежно від різних фракторів. Таврійський науковий вісник. 
2019. № 107. C. 199-204. doi:10.32851/2226-0099.2019.107.27.

5. Войтенко С. Л. Можливість підвищення молочної продуктивності у корів локальних порід. Вісник Полтавської державної аграрної академії. 2016. № 4. С. 72-75.

6. Вплив генотипових та паратипових чинників на ознаки молочної продуктивності корів різних порід / Л. М. Хмельничий, А. М. Салогуб, В. В. Вечорка, О. І. Гаврилюк. Вісник Сумського національного аграрного університету. Серія «Тваринництво». 2014. Вип. 2/1 (24). С. 87-91.

7. Вплив генотипових та паратипових факторів на реалізацію молочної продуктивності корів / С. Л. Войтенко, Т. І. Карунна, Б. С. Шаферівський, І. М. Желізняк. Вісник Сумського національного аграрного університету. Серія «Тваринництво». 2019. Вип. 1-2 (36-37). С. 21-26. doi:10.32845/bsnau.Ivst.2019.1-2.3.

8. Гавриленко М. С. Довічна продуктивність корів української чорно-рябої породи залежно від віку їхнього першого отелення. Розведення і генетика тварин. 2003. Вип. 35. С. 19-26.

9. Гнатюк С. І., Хмельничий Л. М. Формування молочної продуктивності корів залежно від впливу паратипових факторів. Вісник Сумського національного аграрного університету. Серія «Тваринниитво». 2010. Вип. 7 (17). С. 32-35.

10. Ілляшенко Г. Д. Зв'язок молочної продуктивності корів з живою масою і віком при першому осіменінні. Розведення і генетика тварин. Вип. 54. 2017. С. 45-50.

11. Ільницька О. Ю., Федорович Є. І., Бабік Н. П. Молочна продуктивність корів різних ліній прикарпатського внутрішньопородного типу української червоно-рябої молочної породи. Наук. техн. бюл. Держ. наук.-дослід. контрольного ін-ту вет. препаратів та кормових добавок і Ін-ту біол. тварин. Львів, 2015. Вип. 16. № 2. С. 320-324.

12. Косов В. А. Оцінка впливу комплексу факторів на селекційні ознаки молочної худоби. Технологія виробництва $і$ переробки продукції тваринництва: зб. наук. пр./ Білоцерків. держ. аграр. ун-т. 2010. Вип. 3(72). С. 80-83.

13. Кругляк О. В. Формування високопродуктивних молочних стад як чинник підвищення ефективності виробництва молока. Економіка АПК. 2018. № 3. С. 24-31.

14. Новак І. В., Федорович В. В., Федорович $€$. І. Вплив віку першого плідного осіменіння і першого отелення на формування молочної продуктивності корів української чорно-рябої молочної породи. Біологія тварин. 2012. Т. 14. № 1-2. С. 486-490.

15. Підпала Т. В., Бондар С. О. Успадкування селекційних ознак потомством бугаїв-плідників голштинської породи. Розведення і генетика тварин. 2017. Вип.53. С.173-178.

16. Піщан І. С. Генотипові та паратипові фактори формування молочної продуктивності корів швіцької породи в австрійській екологічній зоні походження. Науковий вісник Львівського національного університету ветеринарної медицини та біотехнологій ім. Гжицького. 2016. Т. 18. № 2 (67). С. 187-194. doi:10.15421/nvlvet6742.

17. Порівняльна характеристика молочної продуктивності корів українських червоно-рябої, чорно-рябої молочних та голштинської порід у ДПДГ «Олександрівське» / М. В. Гладій та ін. Розведення і генетика тварин. 2016. Вип. 52. С. 6-12.

18. Пославська Ю. В., Федорович $Є$. І., Бабік Н. П. Вплив сезону народження та сезону отелення корів на їх молочну продуктивність. Науковий вісник Львівського наиіонального університету ветеринарної медицини та біотехнологій ім. Ґжицького. 2015. Т. 17, № 3 (63). С. 297-302.

19. Сидоренко О. В., Войтенко С. Л., Порхун М. Г. Результати оцінки великої рогатої худоби племінних стад дослідних господарств мережі НААН та рекомендації щодо ведення племінної справи у молочному скотарстві. Полтава: ПП Астрая, 2020. 38 с.

20. Скляренко Ю. І., Братушка Р. В., Чернявська Т. О. Вплив сезону отелення корів на рівень надоїв і показники стійкості лактації. Науковий вісник Львівського національного університету ветеринарної медицини та біотехнологій ім. Гжицького. 2011. Т. 13, № 4(3). С. 293-296.

21. Сравнительная оценка быков-производителей красно-пестрой породы крупного рогатого скота по происхождению и качеству потомства методом дочери-сверстницы (Д-С) / И. М. Дунин и др. Вестник КрасГАУ. 2015. № 9. С. 212-218.

22. Стадницька О. І. Вплив плідників на формування молочної продуктивності дочок. Матеріали VIII наукової конференції молодих вчених і аспірантів Інституту розведення і генетики тварин. Чубинське, 2010. С. 69.

23. Українська червоно-ряба молочна порода / М. І. Бащенко та ін. // Селекційні, генетичні та біотехнологічні методи удосконалення і збереження генофонду порід сільськогосподарських тварин / М. В. Гладій, М. І. Бащенко, Ю. П. Полупан та ін.; за ред. : М. В. Гладія і Ю. П. Полупана; ІРГТ ім. М. В. Зубця НААН. Полтава : Техсервіс, 2018. С. 209-253.

24. Хмельничий Л. М., Лобода В. П. Селекційне значення ліній та бугаїв-плідників у формуванні ознак молочної продуктивності їхнього потомства. Вісник Житомирського національного агроекологічного університету. Житомир: ЖНАЕУ, 2013. №1. T. 2 (35). C. 40-45.

25. Хмельничий Л. М., Вечорка В. В. Формування ознак молочної продуктивності корів української чорно-рябої молочної породи під впливом генетичних чинників. Вісник Сумського національного аграрного університету. Серія «Тваринництво». 2019. Вип. 3 (38). С. 62-72. doi: $10.32845 /$ bsnau.lvst.2019.3.9

26. Ben Meir YA, Nikbachat M, Fortnik Y, Jacoby S, Levit H, Adin G, Cohen Zinder M,Shabtay A, Gershon E, Zachut M, Mabjeesh SJ, Halachmi I and Miron J (2018). Eating behavior, milk production, rumination and digestibilitycharacteristics of high and low efficient lactating cows. Journal of Dairy Science101, 1-12

27. Broucek, Jan \& Arave, C.W. \& Kisac, Peter \& Mihina, Stefan \& Flak, P. \& Uhrincat, Michal \& Hanus, A. (2006). Effects of Some Management Factors on Milk Production in First-calf Heifers. Asian-Australasian Journal of Animal Sciences. 19. doi: 10.5713/ajas.2006.672.

28. Mhamdi, N., Bouallegue, M., Frouja, S., Ressaissi, Y., Kaur, S., Ben, M., (2012). Effects of Environmental Factors on Milk Yield, Lactation Length and Dry Period in Tunisian Holstein Cows. doi:10.5772/50803. 
29. Verma, M K \& Sachdeva, Gulshan \& Yadav, A.K. \& Gautam, Srijan \& Ali, M.M. \& Bindal, S.. (2016). Effect of genetic and non-genetic factors on milk yield and milk constituents on sahiwal cattle. 50. 808-810. doi:10.18805/ijar.5711.

30. Senbeta, Ewonetu Kebede. (2018). Effect of Cattle Breed on Milk Composition in the same Management Conditions.

\section{References:}

1. Bazyshyna, I. V., 2017. Formuvannia hospodarsky korysnykh oznak molochnoi khudoby v zalezhnosti vid pokhodzhennia za batkom, linii ta sporidnenoi hrupy [Formation of economically useful features of dairy cattle depending on origin of the father, line and related group]. Rozvedennia i henetyka tvaryn, issue 53, pp. 69-78.

2. Burkat, V. P., 2003. Desiat rokiv vid dnia nabuttia Ukrplemobiednanniam statusu natsionalnoho obiednannia po pleminnii spravi u tvarynnytstvi [Ten years from the date of acquisition by Ukrplemobiednannia of the status of a national association for breeding in animal husbandry]. Kyiv: Ahrarna nauka.

3. Vedmedenko, O. V., 2019. Vplyv henotypovykh ta paratypovykh faktoriv na molochnu produktyvnist koriv [The effect of genotypes and paratype factors on milk productivity of cows]. Podilskyi visnyk: silske hospodarstvo, tekhnika, ekonomika, issue 30 , pp.31-38.

4. Vedmedenko, O. V., 2019. Molochna produktyvnist koriv zalezhno vid riznykh faktoriv [Milk production of cows depending on various factors]. Tavriiskyi naukovyi visnyk, no. 107, pp. 199-204. doi:10.32851/2226-0099.2019.107.27.

5. Voitenko, S. L., 2016. Mozhlyvist pidvyshchennia molochnoi produktyvnosti u koriv lokalnykh porid [Ability to increase milk productivity in cows of local breeds]. Visnyk Poltavskoi derzhavnoi ahrarnoi akademii, no14, pp. 72-75.

6. Khmelnychyi, L. M., Salohub, A. M, Vechorka, V.V. and Havryliuk, O. I., 2014. Vplyv henotypovykh ta paratypovykh chynnykiv na oznaky molochnoi produktyvnosti koriv riznykh porid [Influence of genotype and paratypic factors on signs of milk production of cows of different breeds]. Visnyk SNAU, issue 2/1 (24), pp. 87-91.

7. Voitenko, S. L., Karunna, T. I., Shaferivskyi, B. S. and Zhelizniak, I. M., 2019. Vplyv henotypovykh ta paratypovykh faktoriv na realizatsiiu molochnoi produktyvnosti koriv [Influence of genotypic and paratype factors on realization of dairy productivity of cows]. Visnyk SNAU, issue 1-2 (36-37), pp. 21-26. doi:10.32845/bsnau.lvst.2019.1-2.3.

8. Havrylenko, M. S., 2003. Dovichna produktyvnist koriv ukrainskoi chorno-riaboi porody zalezhno vid viku yikhnoho pershoho otelennia [Lifelong productivity of Ukrainian Black-and-White Breed cows depending on the age of their first calving]. Rozvedennia i henetyka tvaryn, issue 35, pp. 19-26.

9. Hnatiuk, S. I. and Khmelnychyi, L. M., 2010. Formuvannia molochnoi produktyvnosti koriv zalezhno vid vplyvu paratypovykh faktoriv[Formation of milk productivity of cows depending on the influence of paratypic factors]. Visnyk SNAU, issue 7 (17), pp. 323-35.

10. Illiashenko, H. D., 2017. Zviazok molochnoi produktyvnosti koriv z zhyvoiu masoiu i vikom pry pershomu osimeninni [Relationship of milk productivity of cows with live weight and age at the first insemination]. Rozvedennia i henetyka tvaryn, issue 54, pp. 45-50.

11. Inytska, O. Yu., Fedorovych, Ye. I. and Babik N. P., 2015. Molochna produktyvnist koriv riznykh linii prykarpatskoho vnutrishnoporodnoho typu ukrainskoi chervono-riaboi molochnoi porody [Milk yield of cows of different lines of prykarpatska internal type of Ukrainian Red-and-White Dairy Breed]. Naukovo-tekhnichnyi biuleten Derzhavnoho naukovo-doslidnoho kontrolnoho instytutu veterynarnykh preparativ ta kormovykh dobavok i Instytutu biolohii tvaryn, issue 16, no. 2, pp. 320-324.

12. Kosov, V. A., 2010. Otsinka vplyvu kompleksu faktoriv na selektsiini oznaky molochnoi khudoby [Estimation of influence of a complex of factors on selection signs of dairy cattle]. Tekhnolohiia vyrobnytstva i pererobky produktsii tvarynnytstva: zb. nauk. pr., issue 3(72), pp. 80-83.

13. Kruhliak, O. V., 2018. Formuvannia vysokoproduktyvnykh molochnykh stad yak chynnyk pidvyshchennia efektyvnosti vyrobnytstva moloka [Formation of highly productive dairy herds as a factor of increasing the milk production efficiency].Ekonomika APK, no.3, pp. 24-31.

14. Novak, I. V., Fedorovych, V. V. and Fedorovych Ye. I., 2012. Vplyv viku pershoho plidnoho osimeninnia i pershoho otelennia na formuvannia molochnoi produktyvnosti koriv ukrainskoi chorno-riaboi molochnoi porody [Effect of the age first fertile insemination and the first calving on formation of milk productivity of cows of Ukrainian Black-and-White dairy breed].Biolohiia tvaryn, vol.14, no. 1-2, pp. 486-490.

15. Pidpala, T. V. and Bondar, S. O., 2017. Uspadkuvannia selektsiinykh oznak potomstvom buhaiv-plidnykiv holshtynskoi porody [Inheritance of selective features by offspring of bulls of Holstein Breed]. Rozvedennia i henetyka tvaryn, issue 53, pp. 173-178.

16. Pishchan, I. S., 2016. Henotypovi ta paratypovi faktory formuvannia molochnoi produktyvnosti koriv shvitskoi porody v avstriiskii ekolohichnii zoni pokhodzhennia [Genotypic and paratypic factors formation of milk productivity of Austrian Swiss breed cows in environmental area of origin]. Naukovyi visnyk LNUVMBT im. Gzhytskoho, vol.18. no 2 (67), pp. 187-194. doi:10.15421/nvlvet6742.

17. Hladii, M.V. et al, 2016. Porivnialna kharakterystyka molochnoi produktyvnosti koriv ukrainskykh chervono-riaboi, chornoriaboi molochnykh ta holshtynskoi porid u DPDH «Oleksandrivske» [Comperative description of milk productivity of cows Ukrainian Red -and-White Dairy Cattle and Ukrainian Black-and-White Dairy Cattle and Holstein Breeds in SERF «Oleksandrivske»]. Rozvedennia i henetyka tvaryn, issue 52, pp. 6-12.

18. Poslavska, Yu. V., Fedorovych, Ye. I. and Babik, N. P., 2015. Vplyv sezonu narodzhennia ta sezonu otelennia koriv na yikh molochnu produktyvnist [The influence of season of birth and calving on their dairy production]. Naukovyi visnyk LNUVMBT im. Gzhytskoho, vol. 17, no.3 (63), pp. 297-302.

19. Sydorenko, O. V., Voitenko, S. L. and Porkhun, M. H., 2020. Rezultaty otsinky velykoi rohatoi khudoby pleminnykh stad doslidnykh hospodarstv merezhi NAAN ta rekomendatsii shchodo vedennia pleminnoi spravy u molochnomu skotarstvi [The results 
of the assessment of cattle of breeding herds of research farms of the NAAS network and recommendations for breeding in dairy farming]. Poltava: PP Astraia.

20. Skliarenko, Yu. I., Bratushka, R. V. and Cherniavska T. O., 2011. Vplyv sezonu otelennia koriv na riven nadoiv i pokaznyky stiikosti laktatsii [Influence of the calving season of cows on milk yield and stability of lactation]. Naukovyi visnyk LNUVMBT im. Gzhytskoho, vol.13, no. 4(3), pp. 293-296.

21. Dunin, I. M. et al., 2015. Sravnitel'naya ocenka bykov-proizvoditelej krasno-pestroj porody krupnogo rogatogo skota po proiskhozhdeniyu i kachestvu potomstva metodom docheri-sverstnicy (D-S) [The comparative assessment of the bull-sires of the cattle Red-Motley Breed on the origin and the posterity quality by the method of daughter-peer (D-P)]. Vestnik KrasGAU, no. 9, pp. 212-218.

22. Stadnytska, O.I., 2010. Vplyv plidnykiv na formuvannia molochnoi produktyvnosti dochok [Influence of breeders on formation of dairy productivity of daughters]. Materialy VIII naukovoi konferentsii molodykh vchenykh i aspirantiv Instytutu rozvedennia i henetyky tvaryn. Chubynske. pp.69.

23. Bashchenko, et al., 2018. Ukrainian Red-and-White Dairy Breed. In: M. V. Hladiia and Yu. P. Polupana, ed. Selektsiini, henetychni ta biotekhnolohichni metody udoskonalennia i zberezhennia henofondu porid silskohospodarskykh tvaryn[Selection, genetic and biotechnological methods of improvement and preservation of the gene pool of farm animal breeds]. Poltava: LLC "Techservice Company", pp. 209-253.

24. Khmelnychyi, L. M. and Loboda, V. P., 2013. Selektsiine znachennia linii ta buhaiv-plidnykiv u formuvanni oznak molochnoi produktyvnosti yikhnoho potomstva[Selection value of breeding lines and bulls in the formation of signs of milk productivity of their offspring]. Visnyk ZNAEU, no 1, vol. 2 (35), pp. 40-45.

25. Khmelnychyi, L. M. and Vechorka V. V., 2019. Formuvannia oznak molochnoi produktyvnosti koriv ukrainskoi chornoriaboi molochnoi porody pid vplyvom henetychnykh chynnykiv [Formation of cow's milk productivity traits of ukrainian black- andwhite dairy breeds under the influence of genetic factors]. Visnyk SNAU, issue 3 (38), pp. 62-72. doi: 10.32845/bsnau.Ivst.2019.3.9

26. Ben Meir YA, Nikbachat M, Fortnik Y, Jacoby S, Levit H, Adin G, Cohen Zinder M,Shabtay A, Gershon E, Zachut M, Mabjeesh SJ, Halachmi I and Miron J (2018). Eating behavior, milk production, rumination and digestibilitycharacteristics of high and low efficient lactating cows. Journal of Dairy Science, 101, 1-12

27. Broucek, Jan \& Arave, C.W. \& Kisac, Peter \& Mihina, Stefan \& Flak, P. \& Uhrincat, Michal \& Hanus, A. (2006). Effects of Some Management Factors on Milk Production in First-calf Heifers. Asian-Australasian Journal of Animal Sciences. 19. doi: 10.5713/ajas.2006.672.

28. Mhamdi, N., Bouallegue, M., Frouja, S., Ressaissi, Y., Kaur, S., Ben, M., (2012). Effects of Environmental Factors on Milk Yield, Lactation Length and Dry Period in Tunisian Holstein Cows. doi:10.5772/50803.

29. Verma, M K \& Sachdeva, Gulshan \& Yadav, A.K. \& Gautam, Srijan \& Ali, M.M. \& Bindal, S.. (2016). Effect of genetic and non-genetic factors on milk yield and milk constituents on sahiwal cattle. 50. 808-810. doi:10.18805/ijar.5711.

30. Senbeta, Ewonetu Kebede. (2018). Effect of Cattle Breed on Milk Composition in the same Management Conditions.

Piddubna Liudmyla Mykhailivna, Doctor of Agricultural Sciences, Ph.D

Zakharchuk Daria Valeriivna, graduate student

Korniichuk Dmytro Oleksandrovych, undergraduate

Polissya National University (Zhytomyr, Ukraine)

Assessment of influence of the factor complex on milk productivity of cows

We have studied influence of gene- and paratype factors on the characteristics of milk producing ability of first-calf cows of Ukrainian Black- and-White, Red-and-White and Holstein dairy breeds through absorbing crossbreeding in similar feeding and keeping conditions at PAF "Yerchyky" Popilnia district Zhytomyr region. It was ascertained that genotype factors have dominant influence on characteristics of milk producing ability of cows. Influence of the breed on milk yield is $2.0 \%$, fat content in milk - 4.5\%, protein $3.9 \%$. Milk yield of first-calf cows of Ukrainian Black-and-White dairy breed is $6470 \mathrm{~kg}$, Ukrainian Red-and -White dairy breed $6630 \mathrm{~kg}$, Holstein breed - $6666 \mathrm{~kg}$ with the highest fat and protein content in milk 3.83 and $3.11 \%$ respectively. Influence of linear affiliation on milk yield is $3.6 \%$, fat content in milk - $14.7 \%$, protein content $-15.4 \%$. The highest values of milk yield have first-calf cows of lines Valiant 1650414, Gosco Besna 5694028588, Chifa 1427381 - milk yield 6701-6878 kg, fat content in milk - 3,82-3,86 $\%$, protein content 3.08-3.14\%. Difference max-min between animals of different lines according to said parameters is respectively $811 \mathrm{~kg}, 0.15$ and $0.13 \%$. Characteristics of milk producing ability of daughters are the mostly predetermined by father's genotype milk yield $11.4 \%$, fat and protein content in milk - 31.0 and 31,5\% respectively. Depending on the father, difference max-min by milk yield is $1820 \mathrm{~kg}$, fat content $-0.21 \%$, protein - 0.17\%. Two bulls - Kougar 65439939 and Jarvis 66683713 are especially valuable for selection, their daughters combine high milk yield (over $7000 \mathrm{~kg}$ for 305 days of lactation) with maximum content of fat and protein in milk (3.90 and $3.17 \%$ respectively). One of the paratype factors that influences milk-producing ability the most is the year of calving, which determines milk yield on 14,1\%, content of fat and protein in milk $-30.4-30.6 \%$. In the course of 4-5 years milk yield has increased by $1281 \mathrm{~kg}$, fat content in milk $0.17 \%$, protein $-0.14 \%$. Influence of age and season of calving on milk yield of firstcalf cows is insignificant - 0.7-2.7\%. It has been proved, that live weight of first-calf cows influences their milk yield significantly (20.9\%) which evidences the necessity of intense growing of young cattle.

Key words: influencing factor, milk productivity, breed, line, breeding bull, calving age, year and season of calving, live weight.

Дата надходження до редакції: 13.04.2021 р. 